\title{
Berättelser om idrottshjältar: exemplet Gunder Hägg
}

\section{Av Anders Ohlsson, professor i litteraturvetenskap, Växjö universitet}

\author{
Länk till presentation av Anders Ohlsson
}

\section{Inledning}

När Carolina Klüft, vinnare av 2003 års Jerringpris, tagit emot Växjöbornas hyllningar i Linnéparken i augusti i fjor efter att ha vunnit guld i sjukampen på EM i friidrott, sa hon i en intervju med Aftonbladets Thomas Tynander på sitt anspråkslösa sätt: "Den här lilla medaljen är ju inget jag kommer att tänka på på min dödsbädd, precis. [---] Det är sjukt att lite friidrott kan utlösa en sån stor reaktion hos folk, att så många bryr sig om det lilla jag gjort".[1] För visst är det så att människor i allmänhet bryr sig om tävlingsidrott: i Linnéparken trängdes Växjöborna då i augusti och idrott framstår alltmer som världens mest utbredda form av populärkultur, även om det kan vara vanskligt att exakt ringa in varför den betyder så mycket både för sina utövare och åskådare. En anledning till idrottens attraktionsförmåga är naturligtvis, som idrottsfilosofen Mikael Lindfelt påpekar i sin bok Idrott och moral. Reflektioner över idrottens ideal (1999), att det rör sig om en relativt lättförståelig form av underhållning. En annan är att idrotten svarar mot fundamentala mänskliga behov som gränstestande, lek och inte minst tävlan.[2]

Vad som däremot står alldeles klart är att tävlingsidrott når de allra flesta av oss indirekt: den presenteras - eller representeras - i olika massmedier och texttyper. Ingemar Stenmark hade många åskådare då han for fram i pisterna. Men hur många av dem var verkligen på plats i backen och bevittnade hans framfart med egna ögon? De flesta fick naturligtvis hålla till godo med bilderna i TV eller referaten i radio. Antalet TV-tittare, radiolyssnare samt sportsides- och idrottslitteraturläsare överstiger vida publiksiffrorna på Olympiastadion i München eller på Värendsvallen i Växjö. Den som på plats tar del av en idrottstävling kan numera också se repriser och upptagningar i slowmotion av det som nyss utspelade sig i verkligheten inför ens egna ögon genom att rikta sin blick mot de storbildsskärmar som finns på det flesta arenor. Idrotten är starkt förbunden med - och beroende av - medierna, av de berättelser i ord och bild, vilka låter oss ta del av både tävlingars förlopp och stjärnors prestationer och liv.

En som är väl medveten om att idrott når de flesta av sina åskådare just i form av berättelser - alltså den texttyp där händelser kopplas samman på olika sätt så att vi får en historia med en tydlig början, en mitt och ett slut slut samt en "dubbel kronologi"[3] - är Sydsvenska Dagbladets sportchef Åke Stolt. I sin krönika dagen innan friidrotts-EM 2002 skall ta sin början rapporterar han om hur han och hans journalistkollegor nu skall "skriva sagorna"[4] från mästerskapen.

Detta att själva idrottshändelsen skildras som en berättelse framhöll Roland Barthes, den franske kritikern och professorn i semiologi, redan i mitten av 1950-talet, då han beskrev och analyserade cykelloppet "Tour de France", denna stora mediehändelse, som en hjältedikt: åkarna bär upp handlingen och fyller därmed samma funktion som karaktärerna i de gamla eperna och de förkroppsligar också liksom de episka hjältarna olika egenskaper. Barthes jämför den långa raden av dagsetapper med romankapitel med "absoluta höjdpunkter" och mer utdragna, händelselösa partier. Vidare utsätter naturen - inte minst då under bergsetapperna - åkarna för sådana prövningar som karaktärerna i hjältedikterna tvingas utstå. Barthes skriver: "Tour de France äger alltså en verkligt homerisk geografi. Liksom i Odyssén är cykelloppet här samtidigt en farofylld seglats och en fullständig 
utforskning av jordens gränser".[5]

Men det är inte bara själva idrottshändelsen - tävlingsmomentet, matchen eller loppet - som når sina intresserade åskådare i form av en berättelse. Också det publiken vet - eller tror sig veta - om idrottsstjärnorna är resultatet av de berättelser eller, med Åke Stolts välfunna ord, de "sagor" om dem som de intresserade erbjuds ta del av. För visst är det så som den engelske medieforskaren Gary Whannel påpekar i sin bok Media Sport Stars. Masculinities and Moralities (2002) att idrottares stjärnstatus är ett resultat av representation eller med Whannels ord "narrativisering", dvs. berättande.[6] Dessa mediala idrottsstjärnor framstår allt mer som vår tids aristokrati. Den årliga så kallade idrottsgalan i Sveriges Television framstår allt mer som en idrottsstjärnornas gala och tillsammans med andra av populärkulturens stjärnor tävlar de med statsmän och politiker om mediernas uppmärksamhet. Detta är skäl nog att granska berättelserna om idrotten och dess stjärnor. I idrottens berättelser - i pressens reportage, i etermediernas direktsändningar eller i olika litterära genrer - reproduceras olika samhälleliga föreställningar och ideologier. Där konstrueras vår tids myter och hjältar. Som ett slags laboratorium och som ett uttryck för samhället är idrotten och dess berättelser intressanta och viktiga att studera. Detta framstår så mycket mer som en angelägen forskningsuppgift som humanistiskt inriktad idrottsforskning alltjämt är en bristvara - inte minst när det gäller svenska förhållanden trots att studiet av medierad idrott tagit fart under det senaste decenniet.[7]

Ett självklart intresse i dessa sammanhang tilldrar sig naturligtvis "biografiska berättelser"[8] om de för idrotten så betydelsefulla stjärnorna. Även om man begränsar sig till olika litterära genrer - självbiografier, memoarer och biografier - finns det ett flödande rikt material, något som Gunder Anderssons nyligen utgivna antologi med titeln Idrottarliv (2002) vittnar om. Vidgar man perspektivet till att också omfatta andra texttyper och medier blir materialet i det närmaste ogripbart. En framkomlig väg är då att fokusera på en enskild idrottsstjärna och för egen del har jag stannat för Gunder Hägg. Han är född 1918 och var under andra världskriget svensk medeldistanslöpare i absolut världsklass. Under sin karriär satte Hägg femton världsrekord. Han blev, med mediernas hjälp, en nationalidol utan tidigare motsvarighet i vårt land: andra länder hade sina krigshjältar - Sverige hade Gunder Hägg. Det handlar enligt den svenske medieforskaren Peter Dahlén, och särskilt under Häggs USA-turné 1943, om en "i Sverige ditintills kanske aldrig tidigare skådad idoldyrkan".[9]

Många läsare har vittnat om vilket intryck berättelserna om Hägg gjorde. Ett exempel är den ovan nämnde Gunder Andersson: redan förnamnet förpliktigar ju! I en av sina böcker beskriver Andersson hur han i unga år levde på Hägg-drömmen. Han berättar om överambitiösa träningspass: 5 km morgon och kväll, sommar som vinter, vardag som julafton.[10] Varifrån kom då inspirationen? Andersson nämner själv den förre värlsrekordhållarens Gunder Häggs dagbok (1952). Här upptas ett flertal sidor av enformiga listor där Hägg dag för dag förtecknat sin träningsdos. Utformningen är naturligtvis ägnad att framhäva envetenheten och beslutsamheten hos honom och manade alltså till efterföljd. Men för Gunder den andre - alltså Gunder Andersson - resulterade den plågsamma träningen inte i någon vidare framgång, utan endast i ett smärtande knä.[11]

Mitt val av Gunder Hägg beror förutom på att han var den förste verkligt store, svenske mediala idrottsstjärnan också på att det i hans fall finns ett rikhaltigt material i bokform och detta redan från karriärens glansdagar - som infaller efter det att sportbevakningen fått en fast plats i press och radio, men före introduktionen av TV-mediet - och ända fram till slutet av 1980-talet. Därmed är det möjligt att undersöka hur bilden av Hägg har förändrats och skrivits om från en tid till en annan samt att undersöka vilka faktorer som påverkat denna omskrivning. Hägg är förstås intressant i sig men kan också fungera som ett exempel för den som vill försöka förstå hur idrottens mediestjärnor konstrueras och brukas. De frågor som särskilt intresserar mig är vilka värden, teman, hållningar, ideologier och diskurser som cirkulerar i dessa berättelser och hur de bryts mot varandra och förändras över tid, allt läst i ljuset av hur - efter vilka mönster och med vilka grepp - dessa texter är konstruerade. Den bild av Hägg som då framträder kan man relatera till skildringar i andra 
medier såsom press, radio, samtida journalfilmer, vars skildringar i hög grad flyter in i men också utvecklas i de biografiska berättelserna, samt senare i TV. En sådan granskning kan vara på sin plats, i synnerhet som idrottsrörelsen själv, vilket den ovan nämnde Mikael Lindfelt påpekat, förefaller "nästan helt sakna både vilja till och intresse för självkritisk reflektion över den egna verksamheten".[12]

Vilka värderingar och föreställningar finner man då i de biografiska berättelserna i bokform om Gunder Hägg? I det följande skall jag lyfta fram två teman: å ena sidan förhållandet mellan natur och civilisation, å andra sidan stärkandet av försvarsberedskapen mitt under brinnande krig. Dessa båda teman kan kopplas till den socialisation till manlighet som tar sig så tydliga uttryck i berättelserna om Hägg. Idrotten är ju en aktivitet där skillnader i konstruktionen av genus, av vad det innebär att bli man, blir särskilt tydlig.[13]

\section{Mellan natur och civilisation}

Redan samma år, 1942, som Hägg definitivt etablerade sig som världens främste medeldistanslöpare publicerade Gunvald Håkansson sin bok Gunder Hägg slår rekord. En fantastisk idrottskarriär. Den är organiserad enligt ett vanligt mönster i idrottsbiografier och detta mönster beskriver Whannel så här: "triumf - barndom - tidig framgång - första succéen - förbättring - succéer - triumf", alltså ett slags cirkelrörelse.[14] Efter förordets korta påminnelser om sistlidna sommars enorma triumfer, inleder Håkansson en kronologisk skildring och vi förflyttas till de jämtländska skogarna, där en pojke av "skogshuggarsläkt" efter avslutat dagsverke stormar fram på "den barrmjuka stigen", medan hans "garvade jämtlandstorpare" till far tar tiden med en väckarklocka.[15] Det sist nämnda inslaget - det så kallade "väckarklocksloppet" - är ett exempel på det slags anekdoter som ofta förekommer i idrottsbiografier,[16] och i berättelserna om Hägg är detta lopp ett stående inslag; vi hittar det även i hans senaste självbiografi från 1987.[17]

Världens ledande medeldistanslöpare är inte bara ett barn av och ett resultat av det härdande livet i skogen, utan beskrivs även efter sitt genombrott - då han flyttat till Gävle och blivit brandman, vilket var en sporre när hårdträningen inleddes på allvar - som helt beroende av vildmarken för sin träning. Även om naturen beskrivs som Häggs rätta elementet så är alltså hans drivkraft delvis att komma bort ifrån den. Det finns som vi skall se flera sådana till synes paradoxala inslag i Hägg-litteraturen.

Hägg tränar aldrig på löparbanorna, utan drar sig undan till det mytomspunna Vålådalen, till "de svenska idrottsmännens konditionseldorado" för att ladda upp för "nya stordåd".[18] Beskrivningen av denna rörelse mellan natur och civilsation är inte ovanlig i biografiska berättelser om idrottsstjärnor och den följer då gärna, som Whannel påpekat, den heroiska berättelsens struktur: 1 . separation genom avresa från hemtrakten, 2. prövningar och segrar, 3. återkomst och integration i hemmiljön.[19]

Eftersom Hägg vuxit upp i Albacken, en gudsförgäten ort i Jämtland, etableras det i texterna om honom en motsättning mellan natur och civilisation. 1937 inbjuds Hägg första gången att delta i tävlingar på Stockholms stadion. Skogarnas son vandrar runt på huvudstadens gator och förundrar sig över att de maträtter med märkvärdiga namn som han full av förväntan tidigare beställt bara visade sig vara "pärstampa" och "vatten med grädde".[20] Civilisationen och det moderna samhället framställs närmast som dekadensfenomen; storstadslivet förbinds med förfall och förkonstling och ställs i motsats till det enkla livet i skogslandskapen, till den friska luften, till arbetet i det fria. I en mycket intressant passage, som andas stark skepsis till det moderna samhället och dess livsformer skriver Hägg:

Det har måhända även sin stora betydelse att födas och fostras lite borta från de stora vägarna och de stora städerna. Vi som växer upp på landsbygden, i små samhällen och under små förhållanden, vi lär oss mången gång att tänka lite annorlunda och djupare än folk, som bara rusar mellan bilar och bussar och ideligen störs av telefoner medan vi kan vandra ensamma timme efter timme i 
skogen. Vi upplever på det viset så mycket invärtes, att vi får en helt annan andlig balans än storstädernas söner.[21]

Men mönstret är allt annat än entydigt. Under sin USA-turné 1943, som jag strax återkommer till, då Hägg bl.a. frotterar sig med skådespelarstjärnor i Hollywood, imponeras han av modernitetens allra senaste uppenbarelser: "På hemvägen kände vi oss hungriga och då fick jag vara med om ytterligare en sensation. Signe Hasso körde till en servering och körde in med bilen i baren! Vi satt kvar, fick kaffe och bullar serverade i vår vagn, betalade och satte full fart igen samt körde ut på andra sidan. När öppnar Norma en dylik trafik i Stockholm".[22]

Motsättningen natur - civilisation strukturerar också Henry Eidmarks biografi från 1944: Fantomer på kolstybben. Sannsagan om championlöparna Gunder Hägg och Arne Andersson. Men här är mönstret aningen mer komplicerat, inte minst ur genus-synpunkt. Skogshuggaren och naturbarnet Hägg, som vunnit sin styrka genom "arbete i skogen, vid älv och på åker och äng"[23] kontrasteras mot sin värste konkurrent, den ända fram till 1944 evige tvåan Arne Andersson, den seminarieutbildade, intellektuelle och vältalige storstadssonen. Så långt tycks bilden av de båda antagonisterna bekräfta det mönster för konstruktionen av manlighet med anor från 1800-talet enligt vilket närheten till naturens okonstlade och ursprungliga krafter tjänade som riktmärke för manlig karaktär och identitet. Natur är då ett positivt värdeladdat begrepp och förbinds med styrka, äkthet, stabilitet och framåtanda.[24] Mot bakrund av att enligt detta mönster sådant som lärdom och intellektualism gärna förknippas med svaghet och femininitet, medan kroppslighet får representera virilitet och styrka, dvs. "riktig manlighet"[25], kan det tyckas något paradoxalt att Anderssons löpstil beskrivs som råstark, krängande och kraftfull[26] och kontrasteras mot Häggs smidiga steg. Den senares löpstil beskrivs genomgående med epitetet "flytande". Råstyrka borde enligt det ovan skisserade mönstret ha förbundits med urkraften hos den i skogen uppfostrade, medan smidighet skulle ha passat bra ihop med den intellektuelle storstadsbon. Men här ställs alltså mönstret på ända och en möjlig förklaring är Häggs egen kropp: den 182 cm långe och 68 kilo lätte löparen bryter mot förväntningarna på hur en riktig man från Norrland bör se ut. I Från Albacken till U.S.A (1943) ser han sig tvungen att ursäktande beskriva sina inte särdeles imponerande muskler som "fruntimmersaktiga". Men skriver Hägg, "jag klagar inte på styrkan som sitter i dem". Hans muskler har emellertid fått den "rätta sprätten" genom att den "naturliga" - märk väl inte förkonstlade! - gymnastiken i skog och mark gjort dem "lösa och mjuka - det finns inte något knotigt eller bundet över dem".[27] Som ofta framhållits är manlighet "impregnerad med motsättningar".[28]

De biografiska berättelserna om Gunder Hägg är motsägelsefulla också ur en annan synpunkt. Som den arbetarson från landet han är framställs han å ena sidan som en vanlig grabb och läsarna, inte minst av bildtidningen Se och av Idrottsbladet, får komma nära idolens enkla hemförhållanden. Världsrekordhållare Hägg blir med Peter Dahléns ord "allas 'Gunder' "[29] i en tid då det fortfarande var skick och bruk att tilltala främmande personer med "herr", "fru" eller vederbörandes titel; någon du-reform var ännu inte påtänkt. Hägg förkroppsligar idrottens "meritokratiska" ideologi som vill få oss att tro att framgång inte bara är resultatet av talang utan också av hängivenhet och hårt arbete. [30]

$\AA ̊$ andra sidan blir han till följd av sina exceptionella prestationer - i fallet Hägg kan man exempelvis påminna om den fantastiska sommaren 1942 då han satte tio världsrekord inom loppet av åttio dagar - föremål för den typ av "mytologisering",[31] som enligt Whannel är helt central i den här typen av berättelser: idrottsstjärnan tillskrivs medfödd talang, ja övermänskliga kvaliteter och erövrar Sverige, Europa och världen med hjälp av sin löparförmåga.

\section{Försvarsberedskap och skötsamhet}

Berättelserna om Hägg innehåller från allra första början utförliga skildringar av hur hans hårda träning är upplagd: aktiviteten - "Han gillar [...] att pulsa kilometerlångt i lös-snö. 
Svetten flyter i strömmar" - och dess resultat får utförliga skildringar: "Det är inte bara benmusklerna som förbättras. Höfterna och bäckenpartiet, som är all löpnings centralaxel och där största kraften strålar ut från, får sin ordentliga duvning också".[32]

Här förs det skötsamhetsideal in i texten, vilket är ett så omisskännligt inslag i svensk idrotts ideologi i en tid då man flitigt diskuterar "dansbaneländet" och andra förfallssymptom.[33] I kapitlet "Gunder inpå livet" i Håkanssons biografi sätts ett mönster fram - "äkta", "plikttrogen", "arbetsvillig", "hjälpsam" och "hygglig" - som återkommer i böckerna publicerade under karriärens glansdagar. Syftet är naturligtvis att fostra de unga manliga - läsarna, om ej till stjärnlöpare så till harmoniska, fysiskt välutrustade män: "Skulle Du inte bli rekordhållare eller elitman så kan Du i alla fall vara förvissad om att den tid, som du ägnat åt stärkandet av din kropp, ej är bortkastad. Den ger 100\%-ig utdelning både i trivsel och vanlig prestationsförmåga" [org:s kurs.].[34] Man kan här påminna om den framträdande roll som åtminstone sedan mitten av 1800-talet gymnastik och idrott spelade när det gällde att skapa ett nytt manligt ideal. Tävlan och kroppslig ansträngning kom att framstå som intimt förbundet med detta att vara man. 35] Det handlade inte i främsta rummet om att springa fortast, utan om att "stå pall".[36] Ett återkommande tema i de biografiska berättelserna om Hägg är just kroppens stärkande och uppmaningar till självdisciplin: att aldrig ge upp, att "ägna så gott som all fritid åt tränandet, inför de stora loppen", att idka renlevnad och att tävla med måtta, "maximum en gång per vecka".[37] Den fysiska fostran skulle garantera att unga pojkar inte växte upp till veklingar; idealen hette styrka och återhållsamhet.[38] Och att det är unga pojkar som dessa texter främst riktar sig till råder det inga tvivel om. I förordet till Hur jag blev Gunder Hägg. Träningsråd (1946), som främst innehåller just vad undertiteln lovar, finns ett tydligt och direkt tilltal till de blivande läsarna: "Jag var nämligen 'precis som $\mathrm{Du}$ ' en vanlig enkel grabb med vissa latenta anlag att löpa och på dem byggde jag vidare [...] observera att det finns inget som säger, att inte just Du är född med större anlag och förmer av styrka, smidighet och spänst [org:s kurs.]".[39] Sådana tydliga positioneringar av läsaren - ordet 'du' återkommer ofta i texten - är som Whannel framhållit vanliga i idrottsbiografier.[40] Fenomenet är över huvud taget vanligt i den självbiografiska genren: man kan påminna om Rousseaus Bekännelser från slutet av 1700-talet, där läsaren redan från början bjuds in att så att säga "matcha" sitt eget liv mot författarens. Det finns alltså tydligt didaktiska ambitioner i Hägg-litteraturen och den svenske stjärnlöparen visas fram som en "rollmodell".[41]

Alla dessa utförliga beskrivningar av Häggs träning innebär en indirekt uppmaning till unga svenska män i 1940-talets början att själva idrotta som ett led i stärkandet av vad historikern Torbjörn Andersson beskriver som den "fysiska försvarsberedskapen".[42] En som var klar över Häggs betydelse i sammanhanget var Carl-Adam Nycop i bildtidningen Se, där han redan 1941 skrev: Gunder Hägg "har många kamrater av samma skrot och korn i den svenska vapenrocken. Han är på sätt och vis typen för den svenske soldaten av i dag. Han är fylld av obändig styrka. Han är redo att utlösa den till det yttersta unset av sin förmåga när stunden kräver det. Det är också det svenska folket".[43]

Idrotten kunde användas för att främja det patriotiska sinnelaget och för att stärka försvarsviljan.[44] Användningen av Gunder Hägg som rollmodell för unga manliga läsare kan inte frikopplas från det faktum att hans karriär sammanfaller med andra världskriget. Idrottsprestationer blir en starkt sammanhållande kraft för Sverige i en mycket dyster tid.[45]

Det är alltså inte endast när det gäller den fysiska försvarsberedskapen som Hägg kom till användning under krigsåren. De biografiska berättelserna syftar också till att stärka den mentala eller idelogiska förvarsberedskapen och följaktligen skrivs hans karriär in i andra världskrigets utveckling och Sveriges skiftande hållning till de krigförande länderna. Detta är något som den tyske författaren och sportjournalisten Hans Gebhardt särskilt påpekar i sin bok Gunder Häggs 80 dagar (1976), vilken man kan räkna till den dokumentära genren som värderades så högt i en tid när många författare såg det som sin plikt att rapportera från den så kallade verkligheten. Följaktligen beger sig Gebhardt, som i sin ungdom var en 
gränslös beundrare av Hägg, ut på en resa till Sverige i dennes fotspår. Han placerar in Hägg i ett politiskt och idelogiskt sammanhang genom att visa hur den mytologiska bilden av mästerlöparen konstrueras i veckopressen och där används i nationalistiska syften, för att stärka den svenska kampviljan och visa fram något som svenskarna hade anledning att vara stolta över. Ett av Gebhardts verkliga fynd är det nummer av Se från 1942, där Hägg stormar fram med sin ständige rival Arne Andersson hack i hälarna. Rubriken är lika talande som avslöjande: "Männen som folk talar om: ROMMEL [den tyske fältmarskalk som ledde de tyska styrkorna i Nordafrika, min anm.] och HÄGG presenteras i jättereportage". I dessa reportage skrivs de båda männen samman på ett slående sätt. Såväl "ökenkrigaren" som Sveriges löparchampion sägs fängsla en hel värld. De tillskrivs båda samma hårda farthållning: Hägg "bara ökar och ökar farten" och Rommels framfart beskrivs metaforiskt som en "öken- eller pansarritt" eller ett "stormanlopp" varmed han gör sina erövringar på rekordkort tid. Hägg tillskrivs "energi och okuvlig vilja", vilket kan jämföras med Rommels förmenta "järnvilja och okuvliga beslutsamhet". Den senares "kallblodighet", som fruktas av det brittiska imperiet, svarar vidare mot Häggs vilja att ta hämnd efter det att han stängts av från allt tävlande under nio månader 1941 - 42 för brott mot amatörbestämmelserna och därvid visa "dem [...] vem de stungit hade".

Hägg sätter i sin senaste självbiografi Mitt livs lopp (1987) in sin karriär i en historiskpolitisk kontext och förtiger inte längre som i böckerna från 1950-talet, att han faktiskt deltog i ett lopp på Olympiastadion i Berlin 1941, mitt under brinnande krig: "Själva tävlingarna minns jag inte så mycket av - huvudsaken var att man vann".[46] Där nämner han också, och det inte utan viss stolthet, det reportage ur tidningen Se sommaren 1942, som jag tidigare berört.[47] Man kan uppfatta det som att Hägg - liksom de flesta andra som skriver sin självbiografi - tar tillfället i akt och försvarar sitt handlande, genom att måla upp bilden av en tävlingssugen idrottare som inte bryr sig om världspolitikens växlingar. I Jens Linds TV-film Den allvarsamma leken (1999) påstår han nämligen att han inte ägnade det faktum att det var krig en enda tanke: Han bara sprang!

När krigslyckan vänt och tyskarna led nederlag efter nederlag på Europas slagfält, passade det sig naturligtvis inte att skicka Hägg till Berlin. Han blev istället Sveriges löpande ambassadör i USA, dit han åkte sommaren 1943 för att skapa goodwill, som han med sådan självinsikt säger i Linds ovan nämnda TV-film. Och Hägg lyckades sannerligen. Han vann samtliga sina lopp i USA och den amerikanska pressen, som tidigare misstrott Häggs framfart i världsrekordtabellerna, sparade inte på superlativerna i sina skildringar av "Gunder the Wonder". Hans lopp kunde följas i direktsändning hemma i Sverige - för övrigt de första interkontinentala direktsändingarna i Sveriges Radios historia - och segrarna betydde sannerligen en hel del för den nationella självmedvetenheten. Så möttes Hägg också av Per Albin och utrikesminister Günther samt ett antal höga militärer när han återvände hem i oktober; ett uppvisningslopp på ett fullsatt Stockholms stadion var den effektfulla slutpunkten för Häggs nationella värnplikt.

Om USA-turnén formade sig till en nationell succé, så var den början till slutet på Häggs löparkarriär. Ja, äventyret kan utan tvekan uppfattas som peripetin - den dramatiska vändpunkten eller plötsliga omkastningen - i berättelsen om hans idrottskarriär. Sommmaren 1942 innebär som ovan nämnts Häggs genombrott och han håller alla världsrekord från 1500 till 5000 meter när säsongen är slut. Vintern därpå tränar han hårdare än någonsin, men resan till USA - 25 dagar på en lastbåt över Atlanten - sätter förstås sina spår. De yttre förutsättningarna - dåliga banor - och det inte alltid så imponerande motståndet - här finns ingen Arne Andersson som kan pressa honom - får också negativa effekter. Samtidigt nås Hägg av rapporter hemifrån av hur denne Andersson tar ifrån honom några av hans världsrekord. Ur idrottslig synpunkt är 1943 alltså en förlorad säsong. Och även om Hägg under de två år som sedan återstår av hans karriär lyckas återta några världsrekord, så är Arne Anderssons Hägg-komplex definitivt brutet. Men duellerna dem emellan fortsätter under resten av kriget och inbringar stora pengar till Hägg: det kunde bli 30 000:- på en sommar! När så kriget är över behövs Hägg inte längre och hösten 1945 anmäls han för brott mot amatörbestämmelserna och stängs våren 1946 av på livstid. Det nationella bruket av Hägg framstår som än mer cyniskt i ljuset av det 
faktum att en motsvarande anmälan hösten 1941 endast resulterade i att han blev avstängd under vintersäsongen och var fri att starta då tävlandet upptogs sommaren därpå.

(C) Anders Ohlsson

[1] Thomas Tynander, "'Himla skönt att få komma hem'. Carolina Klüft i tårar när hon hyllades av fansen i Växjö", Aftonbladet, 13/8 2002.

[2] Mikael Lindfelt, Idrott och moral. Reflektioner över idrottens ideal, Nora 1999, s. 9.

[3] Seymor Chatman, Coming to Terms. The Rhetoric of Narrative in Fiction and Film, Ithaca \& London, s. $8 \mathrm{f}$.

[4] Åke Stolt, "Stjärnorna som skall lyftas av mängden", SDS, 5/8 2002.

[5] Roland Barthes, Mytologier (1957), sv. övers. 1970, s. 117 f.

[6] Garry Whannel, Media Sport Stars. Masculinities and Moralities, London \& New York 2002, s. 47.

[7] Jfr Peter Dahlén \& Knut Helland, "Sport og medier. En forskningsoversikt", Norsk medietidsskrift 2002:2.

[8] Lisbeth Larsson, Sanning och konsekvens. Marika Stiernstedt, Ludvig Nordström och de biografiska berättelserna, Stockholm 2001.

[9] Peter Dahlén, Från vasaloppet till radiosporten. Radiosportens etablering och förgrening 1925-1995, Stiftelsen Etermedierna i Sverige 1999, s. 204.

[10] Gunder Andersson, Omstart. Mest om sommaridrott, Sthlm 2001, s. 13-20.

[11] Andersson, Omstart, s. $15 \mathrm{ff}$.

[12] Lindfelt, s. 11.

[13] Whannel, s. 32.

[14] Whannel, s. 60.

[15] Gunvald Håkansson, Gunder Hägg slår rekord. En fantastisk idrottskarriär, Stockholm 1942, s. 14 f.

[16] Whannel, s. 60.

[17] Gunder Hägg, Mitt livs lopp, Stockholm 1987, s. 35.

[18] Håkansson, s. 30. Se även Gunder Hägg, Från Albacken till U.S.A., Stockholm 1943, s. 166.

[19] Whannel, s. 49.

[20] Gunder Hägg, Gunder Häggs dagbok. En världsmästares erfarenheter och

träningsråd, Stockholm 1952, s. $10 \mathrm{f}$.

[21] Hägg, Från Albacken till U.S.A., s. 53.

[22] Hägg, Från Albacken till U.S.A., s. 96.

[23] Hägg, Från Albacken till U.S.A., s. 52.

[24] Jens Ljunggren, "Mellan kropp och natur. Mannens kropp och gymnastikens uppgift", Rädd att falla, Hedemora 1998, s. 128.

[25] Ljunggren, s. 135.

[26] Henry Eidmark, Fantomer på kolstybben. Sannsagan om championlöparna Gunder

Hägg och Arne Andersson, Stockholm \& New York 1944, s. 42.

[27] Hägg, Från Albacken till U.S.A., s. 53.

[28] Claes Ekenstam, "Historisk mansforskning", Rädd att falla, Hedemora 1998, s. 23.

[29] Dahlén, Från vasaloppet till radiosporten, s. 210.

[30] Dawid L. Andrews, \& Steven J. Jackson, "Introduction. Sport celebrities, public culture, and private experience", Sport Stars. The Cultural politics of Sporting Celebrity, ed. Dawid L Andrews and Steven J. Jackson, London 2001, s. 8.

[31] Whannel, s. 56.

[32] Håkansson, s. 49.

[33] Torbjörn Andersson, Kung fotboll. Den svenska fotbollens kulturhistoria från 1800talets slut till 1950, Eslöv 2002, s. 519.

[34] Hägg, Hur jag blev Gunder Hägg, s. 6.

[35] Ljunggren, s. 124.

[36] Ljunggren, s. 142.

[37] Hägg, Hur jag blev Gunder Hägg, s. 32, 44.

[38] Ekenstam, s. 22. 
[39] Hägg, Hur jag blev Gunder Hägg, s. 5 f.

[40] Whannel, s. 58.

[41] Andrews, s. 9.

[42] Andersson, Kung fotboll, s. 518.

[43] Carl-Adam Nycop, "Kampviljan", Se 1941:31, s. 3.

[44] Ljunggren, s. 142.

[45] Johnny Wijk, "Idrott, krig och svenska löparstjärnor: om idrottens samhällsetablering och den massmediala uppmärksamheten kring Gunder Hägg under andra världskriget", Studier i idrott, historia och samhälle, red. Johan R. Norberg, Stockholm 2000, s. 314.

[46] Hägg, Mitt livs lopp, s. 71.

[47] Hägg, Mitt livs lopp, s. 78. 